\title{
Welcoming the Stranger Among Us? The Church of England, Immigration and Race (1955-79)
}

\author{
John Anderson
}

\begin{tabular}{|c|c|}
\hline Date of deposit & 10072019 \\
\hline Document version & Author's accepted manuscript \\
\hline Access rights & $\begin{array}{l}\text { Copyright (c) The Author(s) 2019. Published by Oxford University } \\
\text { Press on behalf of the J. M. Dawson Institute of Church-State } \\
\text { Studies. All rights reserved. This work has been made available } \\
\text { online in accordance with publisher policies or with permission. } \\
\text { Permission for further reuse of this content should be sought from } \\
\text { the publisher or the rights holder. This is the author created } \\
\text { accepted manuscript following peer review and may differ slightly } \\
\text { from the final published version }\end{array}$ \\
\hline $\begin{array}{l}\text { Citation for } \\
\text { published version }\end{array}$ & $\begin{array}{l}\text { Anderson, JP 2019, 'Welcoming the stranger among us? The } \\
\text { Church of England, immigration and race, 1955-79', Journal of } \\
\text { Church and State, vol. Advance article. }\end{array}$ \\
\hline $\begin{array}{l}\text { Link to published } \\
\text { version }\end{array}$ & https://doi.org/10.1093/jcs/csz056 \\
\hline
\end{tabular}

Full metadata for this item is available in St Andrews Research

Repository at: https://research-repository.st-andrews.ac.uk/ 


\title{
Welcoming the Stranger Among Us? ${ }^{1}$
}

\section{The Church of England, Immigration and Race (1955-79)}

\begin{abstract}
:
This article explores the early responses of the Church of England to questions of immigration and race, focusing on the response of the church to immigration legislation, wider church attitudes, and attempts to come to terms with racism within church and society during the 1970s. It draws on material from the church archives and contemporary church press to explain why the church leadership was slow to grasp the nature of the issue, though over time it became suspicious of government approaches to immigration. Increasingly concerned about government and public attitudes towards these questions, and under pressure from minorities and more activist clergy, some within the church leadership began to understand the structural nature of racial prejudice and discrimination. In consequence, they found that even quite modest public interventions put them at odds with politicians, certain newspaper editors and the general public, whether Anglican or not.
\end{abstract}

Questions of immigration and race have been contentious issues in British politics since the early-1960s, and more recently have been complicated further by debates surrounding multiculturalism, the securitization of Islam, and new patterns of immigration following enlargement of the European Union. They are issues that have often proved resistant to reasoned discussion and subject to shameless exploitation. This article explores the responses of the Church of England's leadership to questions of race and immigration, focusing on the period from 1955 - when the Church Times published its first editorial on the issue - until Margaret Thatcher's election victory in $1979 .{ }^{2}$ Drawing heavily on church archives ${ }^{3}$ and the church press, it suggests that whilst the church was slow to understand or respond to issues 
surround race and immigration, by the end of the 1970s some amongst the bishops, if not many of those in the pews, were beginning to understand the structural nature of racial inequality and to edge towards an understanding of what would later be characterised as 'institutional racism' in church and society. Several things seem to have driven this tentative shift: an emerging understanding that the 'liberal consensus' accepted by many politicians was rooted in a deeply problematic assumption about the relationship between immigration control and good race relations; a recognition that government immigration policies were in fact based upon distinction of 'colour' and that certain politicians were willing to play the race card for their own ends; a growing awareness that prejudice was more deeply rooted in society than church leaders had originally thought; and pressure from minority communities as well as a few activist priests and lay people who stressed the need to listen to what migrant communities were saying. This was a slow learning process that reflected the Church of England's position as both an established church with a tendency to steer a 'middle course' on public policy issues, and as a national church that was overwhelmingly white and whose members were often reluctant to accept that there was anything that needed addressing.

\section{New Challenges for Polity, Society and Church}

Immigration to Britain was by no means a modern phenomenon, with different peoples arriving as invaders, settlers, refugees, slaves or labourers over many centuries. Often issues of ethnicity and religion came together to create particular tensions for incoming groups, from Jewish communities in medieval England to Irish 'papists' from the late nineteenth century onwards, and then 'Hindu' and 'Muslim' migrants in the last third of the twentieth

century. ${ }^{4}$ What changed in the post-1945 era was the scale of immigration as parallel 
processes of decolonisation and the need for labour in some sectors of the economy, led to a growth in immigrant numbers, from the West Indies in the first instance, and then in growing numbers from South Asia. Ostensibly the governments of the day welcomed immigration but, as John Solomos and Les Back point out, they were already seeing immigration as problematic from the beginning of the decade. ${ }^{5}$ Concern about 'the colour problem' grew from the end of the 1950s, revolving in particular around the impact of immigration on jobs, housing and welfare. ${ }^{6}$ Much of the public discussion revolved around a vision of integration which effectively focused on 'them' as needing to learn the rules of 'our' club - though it was rarely put quite like that. There was also a growing concern about both discrimination and incidents of racial tension, as evident in the 1955 bus drivers' strike in West Bromwich over the hiring of an Indian employee and more dramatically, in the summer of 1958, with racially motivated disturbances in Notting Hill and Nottingham. Whilst Whitehall temporised over what to do, some Conservative politician began to agitate for immigration controls. ${ }^{7}$ The first Commonwealth Immigrants Bill was introduced towards the end of 1961 and approved by parliament on 1 July 1962, being defended by Home Secretary Rab Butler as a 'sad necessity'. 8

This restrictive approach was encouraged by the increasingly racialisation and politicisation of the issue by several Conservative politicians during the late 1950s and early 1960s. Though Labour opposed the 1961 legislation, they kept the law after coming to power and their own Commonwealth Immigrants Act (1968) sought to restrict further those entitled to British citizenship. Tensions were further exacerbated by Conservative MP Enoch Powell's 1968 intervention where he spoke of seeing 'rivers of bloods' in British cities should nothing be done to stem immigration, a speech which David Goodhart sees as rendering sensible debate about race impossible for a generation. ${ }^{9}$ Policy debates about race 
and immigration continued into the 1970s with further immigration legislation in 1971, but by the mid-1970s the discussion was taking place in a different context, as right wing groups like the National Front appeared to be making some political headway. In response some Conservative MPs flirted with more colourful rhetoric about race, and in January 1978 Conservative leader Mrs Thatcher spoke of peoples' fear of being 'swamped by people of a different culture'. ${ }^{10}$

During these years the leadership of both main parties appear to accept rather uncritically the claim of a causal relationship between immigration control and good race relations, and were keen to be seen 'doing something' when in power. ${ }^{11}$ As Chris Waters noted, within immigrant communities attitudes were changing and question were being raised, in ways that to some extent ran parallel to contemporary US debates though the context was very different, about whether members of these groups should accept the often well-intentioned but rather paternalistic support of white liberals who sought to control the terms of the debate.

${ }^{12}$ Black mobilisation became increasingly important, albeit with some debate about who had the right to speak for communities, and there was growing criticism of the failure of the major political parties to advance minority electoral candidates or provide adequate representation within party organisations.

In the decade when immigration began to emerge as a political issue the position of religion in Britain was changing. In the first post-war decade organised Christianity appeared stronger than it had been for many years, with reported growth in church membership and 
participation in baptism and confirmation for most of the Protestant churches. ${ }^{13}$ Yet within a few years institutional Christianity and the Church of England appeared to be in crisis, as many seemed increasingly indifferent to, or drifted away from, religious institutions. Callum Brown suggests that this happened in large part because 'discursive Christianity lost its power', as people no longer accepted the right of established authority to determine their personal choices, whether that authority be religious, social or political. This was evident in the discussions around homosexuality and divorce, in the treatment of sexual matters in literature and the theatre, and in the satire boom which challenged established authority of all sorts, but particularly that of a scandal ridden and tired Conservative administration. ${ }^{14} \mathrm{In}$ consequence, what Grace Davie described as the 'Anglican decade' of the 1950s was succeeded during the 1960s by declining self-confidence on the part of the churches, and a search for 'relevance' that had little impact in halting numerical decline. ${ }^{15}$ For all that, the Church of England remained an established church, one whose 'privilege' no longer restricted the religious freedom of other faith communities but did give it more access to politicians and civil servants, as well as representation in the House of Lords, which in turn gave it a greater voice in debating public affairs. ${ }^{16}$

For Davie, the churches failed during this period to take advantage of 'an unexpected opportunity for growth - never mind renewal - as black (mostly Afro-Caribbean) Christians arrived in the major cities', and she suggests that the failure to take this opportunity is 'one of the saddest indictments of mainline Christianity in this period'. ${ }^{17}$ The Church of England's failure was in some ways surprising, given that its churches and ministers had been active and often significant actors in British colonies, and some had begun to return to the UK as decolonisation took off. A few did take an active part in debates over immigration, whether prominent figures like Fr Trevor Huddleston, effectively expelled from South African in 
1955 because of his anti-apartheid activities, ${ }^{18}$ or Rev Paul Burroughs who returned from Rhodesia in the late 1950s. As the Bishop of Birmingham's chaplain for overseas people, Burroughs played a significant role during the mid-1960s in trying to get the church and local authorities to take seriously the needs of immigrant communities,. ${ }^{19}$ Simultaneously, the Anglican Communion was undergoing a very uneven and slow process of decolonisation, as national or regional provinces became independent of Canterbury, and control over the appointment process was gradually ceded from the Crown and Canterbury to local church organisations. ${ }^{20}$ Church authorities in England were also increasingly engaged with the issue of discrimination under the apartheid regime in South Africa and, from the early 1960s, in debates over the 'Rhodesian' problem as white settlers refused to accept majority rule. ${ }^{21}$

The first Church Times editorial on the subject, entitled 'Strangers in our midst', appeared on 18 March 1955. Noting anti-immigrant sentiments expressed by some members of the public, it attacked those "who played on the emotions of ignorant people with crude and offensive slogans', and suggested that once 'the immigrants have arrived it becomes a human and not a political question'. ${ }^{22}$ This editorial set the tone of the relatively limited discussion of the issue over the next five years, as church leaders assumed that most citizens were fundamentally tolerant, that prejudice was based primarily on misunderstanding, but also that the issue had the potential to be exploited. The attitude to immigrants displayed by this and other church commentary was often rooted in good will but took on board numerous stereotypes about whole communities and often reflected a degree of conscious or unconscious racial superiority. ${ }^{23}$ The church press published a number of letters as the $1950 \mathrm{~s}$ progressed, some supporting integration and acceptance, ${ }^{24}$ but others more hostile. Sexual anxieties were often to the fore, with one vicar asking whether 'intermarriage between Black and White is no longer to be regarded as undesirable? If so, I imagine that there will a large 
body of opinion, both Black and White, which will feel unable to accept this standpoint'. ${ }^{25}$ In this context it is perhaps not surprising that many sources outlined the lack of welcome extended to immigrants in many churches, with one study noting the case of a vicar telling a black couple not to come again because his 'congregation wouldn't like it'. ${ }^{26}$

\section{The Church Engages}

Archbishop Ramsey and the Commonwealth Immigrants Acts

One of Michael Ramsey's first tasks after taking office as Archbishop of Canterbury in mid1961 was to address the immigration issue. A man of non-conformist upbringing and liberal politics, a scholar by nature, he had little experience in this area, but over time became aware of the seriousness of these issues and wary of the immigration policies of successive governments. ${ }^{27}$ By 1961 pressure for restriction on immigration was growing, with Conservative MP Cyril Osborne leading the charge. Writing in The Church of England Newspaper, Osborne accepted that all were equal before God, but at the same time 'haven't the English people living in England the right to say who shall come and live in their country? Of course they have'. Discussing the growing size of the immigrant population he was quite clear. 'I want all immigration controlled. Colour, of course, brings in added difficulties. Nowhere in the world has the race problem been solved. Surely it is criminal folly to bring the problem into our own country unnecessarily'. ${ }^{28}$ A Canon Hutchinson wrote, suggesting that whilst prejudice is unacceptable, 'segregation is a law of nature....As a nation we are under no compulsion to admit without discrimination people, of whatever colour, who will turn our cities into slums and our streets into hotbeds of vice'. ${ }^{29}$ In response, Rev Kenneth Leech suggested that 'however much these pleas may appear in the pious 
wrappings which insist on no discrimination against race, creed or colour, they are pleas which derive all their substance from colour...Sir Cyril has said himself that he wishes to keep England a white man's country. Let us therefore drop the disguises and see the scheme for what it is: a racialist measure'. ${ }^{30}$ By the end of 1961 the two main Anglican papers were broadly supporting immigration controls on the grounds that they would help to reduce racial tensions. The Church Times took a robust view, supporting the proposal requiring would-be immigrants to have a job to come to and be people of good health and good conduct. It felt that legislation along these lines would be 'thoroughly sensible' and that 'colour and race are beside the point. It is impossible for one small and overcrowded Britain to continue indefinitely to allow unrestricted immigration'. ${ }^{31}$

The Commonwealth Immigrants Bill circulating in late 1961 - and approved by parliament on $1^{\text {st }}$ July1962 - proposed to control immigration, create a voucher system for those eligible to work, deport those immigrants who were here illegally, and raise the qualifying time for British citizenship from one to five years. ${ }^{32}$ In November that year the Church of England's Board of Social Responsibility (BSR) put out a statement which expressed regret that 'it has been thought necessary to deal with Commonwealth immigration by means of legislation... whilst not disputing the principle that a government has the right to control immigration'. ${ }^{33}$ As the bill progressed, the Board repeatedly stressed that exclusions should not be made on the basis of race, nationality or religion, and rather optimistically claimed that 'any suggestion of inferiority and superiority of peoples on the basis of colour or race is repugnant to the majority of British people whatever may be the existing differences in culture, standard of living, and social organisation'. ${ }^{34}$ 
Introducing the Bill in the upper house, Lord Kilmuir, the Lord Chancellor, said that it was his 'distasteful duty' to bring forward this bill given that on paper nearly a quarter of the world's population had the right of entry under existing arrangements. The Archbishop noted that rarely had a bill been introduced with so little enthusiasm and suggested that it was indeed 'lamentable that this reversal of a great tradition of our country should have happened... There is no doubt that the introduction of this Bill caused something of a shock of feeling overseas'. He accepted, perhaps naively, that there was no intent of colour discrimination on the part of the government and that it was seeking to deal with genuine problems, but suggested that there was a need to 'set about attacking with far greater vigour those conditions which have created any case whatever for this proposal of restriction'. ${ }^{35}$ Quite what he meant seems unclear, ${ }^{36}$ and the following day Conservative peer Lord Hailsham sent him a note suggesting that his speech had created the wrong impression, as he had thought Ramsey was intending to say that the Bill was a lamentable necessity whereas the press was saying that he had condemned the bill as lamentable. ${ }^{37} \mathrm{Fr}$ Kenneth Leech, a prominent clerical critic of government policy and the limited church response, was also unsure whether Ramsey was opposing the bill, but reports that towards the end of his life Ramsey told him that the bill should not have been passed and the case for control was a poor one. Given Ramsey's increasingly outspoken critiques of racism and later legislation, it is likely that in 1962 he was on a steep learning curve and, in Leech's interpretation, perhaps 'somewhat innocent about the degree of racism within the government'. ${ }^{38}$

Whilst Labour had opposed the 1962 Act and condemned racist politics during the election campaign, the incoming Labour government decided to leave the act in place and in 1965 issued a White Paper proposing further restrictions on immigration. Simultaneously it sought to balance this by supporting a rather limited Race Relations Act. During the 1960s 
there were several attempts to introduce race relations legislation and some of the early debates around these demonstrated the naivety of many senior churchmen about the depth of the problem. Addressing a Lords debate on such a bill in May 1962 Robert Stopford, the Bishop of London, said that whilst sympathetic to legislation he feared that it might exacerbate problems rather than ease them and asked whether it might be wiser to "continue to work through education and mutual understanding to remove the causes of racial distrust and discrimination'. ${ }^{39}$ To what extent this rather distant bishop was aware of the situation on the ground is less clear, but his preference for non-intervention on the grounds that it might make matters worse was a frequent refrain in later church debates, even as it was increasingly challenged by black and white activists within the churches. The 1965 Race Relations Act offered a fairly limited definition of what counted as racial discrimination; a further law in 1968 was to extend the definition to include housing and employment. ${ }^{40}$ During these later debates the bishops were broadly supportive of legislation though still stressing that legislation was only one step, along with creating more economic opportunities and educating society, to ensure the creation of genuinely tolerant society. ${ }^{41}$

Alongside the 1965 proposal for restricting immigration further, Labour created a National Committee for Commonwealth Immigrants (NCCI) whose aim was 'to promote and co-ordinate on a national basis efforts directed towards the integration of Commonwealth immigrants into the community’. On 5 August 1965 Prime Minister Harold Wilson wrote to Archbishop Ramsey asking if he would be willing to chair this body. ${ }^{42}$ Ramsey had some reservations about moving so close to the cut and thrust of British politics but his biographer suggests that he saw this as a way of contributing to ensuring 'racial harmony in a Britain which was now bound to be multi-racial'. ${ }^{43}$ Rev Wilfred Wood, later to be the first black Anglican Bishop in England, wrote to Ramsey asking how he could accept this position given 
that the government's white paper 'reveals a policy racial in content and hypocritical in purpose'. Ramsey responded that despite his narrow brief, he would not hesitate to criticise immigration controls if they hindered the task of integration. ${ }^{44}$ At its first meeting the NCCI immediately went beyond its brief in noting the widespread disquiet felt amongst immigrant communities about what were widely seen as racist controls, and Ramsey wrote to Wilson stressing this point again. ${ }^{45}$

During the three years of the NCCI's existence the archbishop did not play a hands-on role but served as a resource for the committee when it sought to address or confront government, or needed to get public statements into the media. During this time one has the impression of a man who is learning rapidly about the extent of prejudice and discrimination, about the ways in which politicians played to the public and press gallery on this issue, about the internal politics of activists claiming to speak for ethnic communities, and about how many ostensibly progressive social organisations such as trade unions struggled to throw off prejudice. For their part, Labour politicians found him less compliant than they had hoped. In December 1966 he wrote to the prime minister suggesting that the first year of their work had demonstrated the impossibility of separating out integration from immigration issues, and suggested that there was 'an embittered sense of apartness' growing in the minds of the immigrant community who believe that current controls do discriminate on grounds of colour. ${ }^{46}$ These and other interventions led a Daily Express columnist to suggest that 'there are some truly dangerous men when it comes to race relations. Let me name perhaps the most dangerous of them all: Dr Michael Ramsey, Archbishop of Canterbury... All kinds of dubious things go on under Dr Ramsey’s soppy aegis’. ${ }^{47}$ 
1968 was to prove a critical year for Ramsey's interventions on this issue. In February Home Secretary Jim Callaghan pushed through a hastily conceived Commonwealth Immigrants Act to prevent Kenyan Asians holding British citizenship from entering the country in the wake of the Kenyan government's Africanisation policies. Liberals may have protested, but Callaghan was unsentimental and alert to the concerns of working class voters in those areas where most of the immigrants had settled. ${ }^{48}$ During the debate on the act in the House of Lords on 29 February Ramsey made much of the likely effect of this legislation on race relations in the country, and suggested that the 'sudden launching' of this bill on the country has caused dismay to those working in the field and distrust amongst immigrant communities. He went on, 'Why distrust, my Lords? Because the Bill virtually distinguishes United Kingdom citizens on the score of race, and because the Bill virtually involves this country in breaking its word'. He noted that technically the Kenyan Asians will retain citizenship but not one that allows them into this country, which means that it is 'devoid' of any real meaning. ${ }^{49}$ Within the NCCI there were discussions of a mass resignation and, in an obvious bid to prevent the bad publicity that would ensue, the Home Secretary wrote to Ramsey trying to prevent his departure. ${ }^{50}$ After the act was passed, Ramsey wrote to Harold Wilson saying that the NCCI was completely by-passed in drafting this legislation and that goodwill had been undermined amongst the immigrant community. Several Asian members subsequently resigned in March and April 1968, and in May Ramsey made it clear that he felt unable to take on chairmanship of the Community Relations Commission which was to replace the NCCI under the new Race Relations Act. ${ }^{51}$

Though Ramsey stepped back from such intense involvement after 1968, he continued to express concern at the language of the immigration debate. He was critical of the immigration bill introduced by the new Conservative government in 1971, arguing that it was un- 
necessary and would only strengthen the difference between white and non-white entitlements. He also expressed concern about the implications for divided families and the very weak appeals procedure for those subject to deportation, ${ }^{52}$ and voted against the bill in the House of Lords ${ }^{53}$ In 1973-4, the archbishop was also to oppose unsuccessfully the attempt to apply retrospectively clauses relating to the deportation of illegal immigrants, ${ }^{54}$ but he was happier with the resolution of the Ugandan Asian crisis which arose in August 1972 when Idi Amin ordered all Asians to leave the country within ninety days. Around 50,000 were British passport holders and Amin said Britain should take responsibility for them. ${ }^{55}$ The archbishop took the view that Britain had a moral and legal obligation to these people, and the churches led by the British Council of Churches and the Catholic Committee for Racial Justice, helped to co-ordinate activity aimed at receiving potential immigrants. Though some in the government temporized, the Home Secretary Robert Carr believed that Britain did have an obligation to people who would potentially be stateless, a position which dismayed Enoch Powell who agreed that we should take our fair share but argued that Britain had no legal obligations to take them all. ${ }^{56}$

The language of prejudice

1968 saw not only a new Commonwealth Immigrants Act but, in April of that year, Enoch Powell's explosive intervention into the debate. ${ }^{57}$ Ramsey was frustrated by what he saw as Powell's 'council of despair' that ruled out any possibility of 'harmonious racial integration'. He was also disturbed by the amount of hostility his own activities generated, and on several occasions speeches or sermons by the archbishop were interrupted by protestors shouting 'shame' or 'traitor'. ${ }^{58}$ In June 1968 the police reportedly warned Ramsey that there had been 
a threat to assassinate him, and offered him police protection. ${ }^{59} \mathrm{He}$ and Enoch Powell continued to spar indirectly, with the archbishop criticising the latter's calls for repatriation in November 1968, and the outspoken MP attacking Ramsey and other critics for living 'on the other side of a comprehension gap' from that inhabited by most British people. ${ }^{60}$ The volume of hostile mail after Powell's speech shocked Ramsey anew, though he had already got a sense of how widespread prejudice was from critical correspondence during his time at the NCCI. In September 1965 a Mr T.Jones had written to protest against the integrationist impulse of the NCCI, claiming to speak for the 'vast majority of indigenous peoples of Britain, when we say that integration is a myth and we reject a multi-racial society. The immigrants who you wish to foist upon us will never be peacefully absorbed. By your efforts to bring about "integration" you are merely promoting miscegenation which is abhorrent to every decent white man and should be equally abhorrent to the coloured immigrant. Your work is subversive and against the interests of this nation'. For Jones, the options were integration, segregation, or repatriation and only the third could solve the problem in a way satisfactory to both sides, and he expressed astonishment that a church leader should head a body dedicated to 'mongrelising our people'. Such letters pointed to the deep anxieties and prejudices to be found amongst part of the white population, and reminded Ramsey that away from the formally civilized discourses of Westminster there were other narratives that some politicians were willing to exploit. ${ }^{61}$

Within the church public discourse was generally less abusive in tone but often no less prejudicial, as illustrated by an exchange of letters in the Church Times during 1965. The correspondence was sparked by a letter from the Rev P. Lyons who suggested that the church needed to be more pro-active in addressing racial bitterness and to address the housing and employment problems of young immigrants. One week later Isla Atherley responded that the 
only way to deal with the problem was 'to wipe out the cause... which is the invasion of our country by races of disparate stock'. She argued that each group has a right to preserve and develop itself, so we need to end immigration and repatriate those already here so as to stop digging the grave of our own civilisation. In response Derrick Lowe asking how Atherley reconciled her comments with St Paul's injunction that in Christ there was neither Jew nor Greek, and why she saw no sense of obligation arising from the fact that many of these immigrants had been dumped in their countries by British slavers. He went on to suggest that on her logic New Zealand Maoris and North American Indians could demand the repatriation of all persons of Anglo-Saxon or Celtic blood. For its part, the Church Times gave Lyons the last word, with a full page article summing up the debate, where he noted that all but one of the letters sent to him had been hostile and many characterized by sexual anxieties. In response he argued that what was most needed was a positive Christian response that took the gifts of all and used them for the wider service of the church. ${ }^{62}$

Ramsey's criticisms of Powell elicited a strong response from members of the public and the church, One volume of Ramsey's papers contain over 120 letters sent to him in 1968, some supportive but many hostile and abusive. They came from a wider range of people, from Lords and MPs, to ordinary people concerned about what was happening in their neighbourhoods. Not untypical of the hostile letters was that of a pensioner from Hounslow who said that whilst he was not a racialist, he felt the archbishop was completely muddled over race relations legislation which effectively discriminated against the white population, even as immigrants have taken 'advantage of our tolerance and generosity... for the price of a fare to this Country'. ${ }^{63}$ Other letters focused on overcrowding, often linked to sexual anxieties about 'swarms of over-sexed, over-breeding' immigrants. ${ }^{64}$ Many supported Enoch Powell, suggesting he was more in touch with ordinary citizens than people like 
Ramsey who, living in grand palaces or in wealthy white suburbs, did not understand the situation of ordinary people, and were all too easily influenced by 'sentimentalists' or 'intellectuals'. ${ }^{65}$

The fight against racism in the church and beyond

During the 1970s the Church of England began very hesitantly to engage with the fight against racism. Church leaders and some officials of the Church's Board of Social Responsibility (BSR) questioned previous assumptions about the innate tolerance of the British people and the belief that with proper education most would in time come to accept the presence of the new immigrant communities. Some clergy were becoming aware of the realities of immigrant life and the facts of racial prejudice in their own parishes, and within the church there emerging a small cohort of more radical voices challenging complacent attitudes. A key stimulus to renewed awareness and debate was provided by Colour and Citizenship (1969), a report commissioned by the Institute of Race Relations, which documented in great detail the discrimination and prejudice faced by Britain's immigrant communities. One small section of the report noted how many immigrants found British churches unwelcoming or cold in their worship styles, with many church people taking the view that in church, as in society, all integration required was that newcomers adapt to our ways. ${ }^{66}$ When the report was debated in the House of Lords on 16 December 1969, the Archbishop of Canterbury agreed that the church had done too little in this area, though he also pointed to individual parishes where multi-racial communities were being built. He noted that the British Council of Churches (BCC) was establishing a Community Race 
Relations Unit (CRRU) and that the two archbishops were appointing community relations officers to advise them in this area. ${ }^{67}$

At the beginning of 1975 Ramsey was replaced by Donald Coggan as Archbishop of Canterbury, a man who Kenneth Leech described as a kind and caring man with no comprehension of the issues. ${ }^{68}$ This was certainly a view that took hold amongst some activists and agencies following speeches made by Coggan in mid-1976, where he suggested that there had to be a clearly defined limit on the number of those entering and full support for the forces of law and order in dealing with those entering illegally. He also stressed the need to recognise that Britain was a multi-racial society, suggested that harsh language about race and immigration hindered attempts at reconciliation, and denounced racist marches as a disgrace to the nation. ${ }^{69}$ On this occasion he found himself attacked from all sides, with the Joint Council for the Welfare of Immigrants expressing concern that he appeared to link black immigration with social problems, whilst Conservative MP John Stokes wrote to say that the archbishop need to show more 'sympathy for the English working class who have to bear the burden of immigration'. ${ }^{70}$

In the second half of the decade church leaders and church members were to be challenged on two fronts - by more radical voices sceptical about what they saw as liberal complacency, and by the fact that some sections of the population supported the agendas of more extreme right wing racist groups. With regard to the first, discussions about race in Britain were often tied into arguments about how best to deal with South Africa and Rhodesia, as the World Council of Churches proved more willing to support the humanitarian activities of liberation movements that used violent means of struggle. Much of the discussion in the churches focused around a 1976 report, entitled The New Black Presence in 
Britain: A Christian Scrutiny, produced by a working group convened by the British Council of Churches. ${ }^{71}$ The group was chaired by Gus John, a Grenada born educationalist and activist with considerable experience of living in and writing about the situation of AfroCaribbean migrant communities. ${ }^{72}$ In his introduction to the report, BCC General Secretary Harry Morton suggested that it would shock those used to a more judicious approach, but recommended it as an 'invitation to Whites to engage with angry and alienated blacks - to see ourselves as others see us'. The introduction by David Sheppard, Bishop of Liverpool, noted the deliberately provocative statement by Gus John who chaired the group, which aimed to shock the reader and produce a change of heart among white British Christians. He suggested that we speak too much about the problems black people bring and not the potential they have to enrich our society, and we don't listen enough to their pain and anger or remember that the Bible speaks of supporting the vulnerable not of some sort of neutral 'fairness'. ${ }^{73}$

John's opening statement suggesting that Britain had treated coloured immigrants as second class production factors, consigning them to decaying industrial areas and refusing to come to terms with its past or the fact that Britain was 'essentially a racist society'. Laying all its social problems at the door of the 'alien wedge', it had since 1962 introduced a series of immigration acts that ushered in an era of institutional racism, whilst politicians made immigrants feel that they do not belong here. Simultaneously, the mechanisms set up for community relations failed to engage with the problems coloured people face and raised the question of why they should integrate, or why white society should dictate the terms in which the black experience was analysed or provide the prescriptions. ${ }^{74}$ The final section of the report produced by the whole group stressed the need to do more to tackle the poor educational opportunities enjoyed by young black people, to address the high rates of unemployment and consequent drift into crime, whilst criticising the general lack of welcome 
in many churches and the tendency to co-opt local leaders into what was essentially 'ambulance work'. ${ }^{75}$

John's section of the report reflected to an emerging British debate about the nature of racism that was beginning to evolve in the mid-1970s and would be articulated in the early 1980s in the Centre for Cultural Studies book The Empire Strikes Back (1982) which linked growing racism and political authoritarianism to Britain's loss of its colonial pre-eminence, and pointed to emerging discussions about institutional racism. Perhaps inevitably this approach was too much for some and a report framed in this way was bound to incite rebuttals, whether from people unsettled by the widespread condemnation of societal and church racism, or from those who felt its language was counter-productive. The theologically conservative Anglican Max Warren, however, took a surprisingly radical view, saying that the report was probably too gentle about the anger felt by many black young people, suggested that integration or assimilation was impossible, and so the emphasis should be on creating 'a culturally plural society'. ${ }^{76}$ John Taylor, the Bishop of Winchester wrote to Harry Morton saying that 'if readers can take the shock of Gus John's abrasiveness and his onesided account of history, if, having got over their own angry response to his anger, they can hear the cry for attention and the sober, caring diagnosis of our tragically unequal society, then the second part of the pamphlet may bring about more actual change than most pamphlets on Social Responsibility have ever done'. Yet he ended by suggesting that this was a very big series of ifs, and the tactics of confrontation were a gamble that might confirm people in their prejudices. ${ }^{77}$

Aware that this was a controversial report, General Synod discussion was delayed from November 1976 to July 1977 to allow for further reflection, and the BSR got together a group 
of Synod members to look at various practical suggestions. These included the possibility of positive discrimination, of addressing the cultural and generational divide within families, of making churches more welcoming, and of exploring discrimination in housing and education, as well as in the police. ${ }^{78}$ The motion introduced before General Synod by Graham Leonard, Bishop of Truro and Chairman of the Board in July 1977, suggested that 'the emergence of a multi-racial and multi-cultural society lays upon the Church the duty to use this opportunity for the enrichment of our national and personal life'. It suggested that the government should adopt policies of positive discrimination or affirmative action in employment and other areas based upon identifiable need, welcomed the creation of the Commission on Racial Equality established by the 1976 Race Relations Act to support integration but with very limited legal powers to tackle discrimination - and enjoined the churches to do more. A four hour debate ensued in which a variety of views were expressed, with one speaker welcoming Black Presence but also suggesting the need to recognise white pain and anxiety, another arguing that the category of 'black' needed unpacking further, and a third doubting whether there was as much discrimination as claimed. In an overwhelmingly white Synod only a couple of people of colour spoke, Vijay Menon a rather conservative lay member suggesting that colour hadn't hindered his professional or church life, and Canon Ivor Smith Cameron who focused on the lack of representation of minority voices in church bodies, and called on the government to send a signal by welcoming the emergence of a multi-racial Britain. The eventual motion passed called upon Christians to stand firm against those who 'advocate racial hatred and division', spoke of the need for 'positive policies of help' - as opposed to positive discrimination - and asked the Board to create another working group, most of whose members would come from minority groups, tasked to develop a special fund to finance minority community projects. ${ }^{79}$ 
This discussion was taking place at a time when extremist groups were becoming more active and prominent, and counter-actions were being organized. Most serious was the threat posed by the National Front which was openly racist and whose programme was described by Gerald Ellison, the Bishop of London, as 'particularly offensive to Christians, who by their loyalty to Jesus are committed to promoting love among all men'. ${ }^{80}$ In August 1977 Mervyn Stockwood, the Bishop of Southwark, participated in a demonstration against racism in Lewisham, though the event descended into violence as National Front members came into conflict with left-wing marchers. ${ }^{81}$ In November the General Synod refused to ban church employees from being members of the Front, but the Archbishop of Canterbury signed a Statement on Racism that specifically condemned it. Nonetheless, a few mostly elderly or retired clergy did join, and in April 1978 the Rev R.A.Bontoft de St Quentin wrote to Coggan saying that he had joined the Front, because 'I believe that their call for a new pride in our national traditions and our country, the firm restoration of law and order are sorely needed...I do not support the NF ideas about "chucking them all out" but I believe in ethnic integrity'. Archbishop Coggan responded that he too shared a pride in national tradition but does not turn to the National Front 'because I do not believe that they really stand for the principles that I value....their blatant racialist policies... are contrary to the Gospel of Christ'. ${ }^{82}$

Within the political arena, Enoch Powell continued to niggle at church engagements with this issue through the late 1970s though, unlike Ramsey, Coggan often preferred not to respond on the grounds that this would only give Powell's views more publicity. More troubling was an interview that Conservative leader Margaret Thatcher gave to ITV's World in Action at the end of January 1978 where she spoke of peoples' fear of being 'swamped by people of a different culture', much to the horror of some of her advisers. ${ }^{83}$ In a private letter to Hugh Whitworth, an aide to the archbishop, Graham Leonard stressed that whilst he 
thought there was a need to raise the issue, it was also necessary to build a multi-racial society and get past current policies which were indeed discriminatory. ${ }^{84}$ David Young, the Bishop of Ripon said that the massive swing to Mrs Thatcher reflected the fears of white people anxious about changes to their community, and the church should be warning politicians that they were playing a very dangerous game, fostering 'emotions and feelings or prejudice, fear and hatred, which can only be destructive to our society'. ${ }^{85}$ The following year Mrs Thatcher would be prime minister and the church would soon be involved in a further round of conflict with the government over the British Nationality Act.

On issues of race and immigration the church was clearly late in grasping the significance of the issue. Its initial response was shaped by its own establishment position, with many senior clergymen accepting uncritically justifications for immigration control put forward by government, and perhaps conditioned by fact that the church was largely a white middle class institution most of whose members had little real sense of the experience of minority communities. As we have seen, it took a while for leading bishops to grasp that immigration policies were indeed largely aimed at 'people of colour', that popular prejudice was more extensive than they imagined, and that discrimination was widespread. Early church statements were often characterised by a patronizing attitude towards people coming from the former colonies, who many church people felt should be welcomed and well-treated but also should assimilate into the existing culture of church and society.

Insofar as the Church ever spoke with a single voice, its position evolved slowly. At the beginning of this period it had considerable experience of thinking about 'moral welfare' and 
socio-economic matters, but few domestic resources to draw on in approaching race and immigration despite the considerable experience of working in former British colonies. In consequence, the 1960s and 1970s were characterised by a very gradual learning process within the church and its key structures that was not dissimilar to that affecting broader educated opinion in the United Kingdom. By the 1970s more radical voices were emerging from within minority communities who were no longer willing to accept what they saw as the platitudes of white liberal society and religious figures keen to help but reluctant to buy into arguments being made about the inherent racism of British society. In his 1984 doctoral thesis Edson Burton noted how the The New Black Presence at least encouraged the churches to take more seriously the need to listen to black voices and accept their emerging critique about the nature of racism and discrimination within Britain, even if many refused to take seriously its message. ${ }^{86}$ This debate would run into the future and debates about black representation on church bodies and in the priesthood, and debates on the nature of multiculturalism. At the end of this period, the Church of England, seeking to ensure internal control over its own policy and demonstrate that it was serious about the issue, appointed the more radically minded Fr Kenneth Leech as the church's first community field officer - and then effectively undermined his position by providing inadequate institutional and financial support. Whilst this may have suggested the church was reluctant to prioritise these issues, it indicated that some at least were beginning to understand their import, and during the 1980s and beyond the Church of England was often to find itself at odds with successive government over issues of race, nationality, immigration and asylum. And these debates have not gone away, with concerns and prejudices about immigration showing their divisive potential once more during many of the debates around Brexit. 
${ }^{1}$ The first part of the title is taken from Welcoming the Stranger Among Us: Unity in Diversity, a statement on immigration issued by the US Conference of Catholic Bishops in 2000: http://www.usccb.org/issues-andaction/human-life-and-dignity/immigration/catholic-teaching-on-immigration-and-the-movement-ofpeoples.cfm (accessed 21 January 2019).

${ }^{2}$ For an overview and discussion of Church of England engagement from an activist priest see K. Leech, 'The Church and immigration and race relations policy', in G. Moyser, ed: Church and Politics Today: The Role of the Church of England in Contemporary Politics (Edinburgh: T\&T.Clark, 1985), pp. 201-20. See also S. Deakin, 'The churches: immigration and race relations' in New Community, 11:1, Winter 1984-5, pp. 101-115; K. Leech, 'The churches - immigration and race relations: a rejoinder to Stephen Deakin' in New Community, 12:2, Summer 1985 pp. 352-3; S. Deakin, 'A reply to Kenneth Leech' in New Community, 13:1, Spring-Summer 1986, pp. 109-110. For a scholarly overview see M.Grimley, 'The Church of England, Race and MultiCulturalism, 1962-2012, in A,Harris \&J.Garnett, ed., Rescripting Religion and the City: Migration and Religious Identity in the Modern Metropolis (Farnham: Ashgate, 2013), pp. 207-21.

${ }^{3}$ The papers of the Archbishop of Canterbury are to be found at Lambeth Palace Library. Papers of the Archbishops cited here will be referred to by their name, volume number, year and fond. I am grateful to the archivists at the Library for their help with accessing material.

${ }^{4}$ CF. R. Winder, Bloody Foreigners: The Story of Immigration to Britain (London: Abacus, 2004); S. Saggar, Race and Politics in Britain (Hemel Hempstead: Harvester Wheatsheaf, 1992), pp. 9-40; H. Gouldbourne, Race Relations in Britain since 1945 (Basingstoke: Macmillan, 1998), pp. 25-49.

${ }^{5}$ J. Solomos \& L. Back, Race, Politics and Social Change (London: Routledge, 1995), p. 44; cf. S.Small \& J.Solomos, 'Race, immigration and politics in Britain: Changing policy agendas and conceptual paradigms 1940s-2000s', in International Journal of Comparative Sociology, 47:3-4, 2006, pp. 235-57.

${ }^{6}$ C. Waters, “"Dark strangers" in our midst: discourses of race and nation in Britain, 1947-1963', in Journal of British Studies, 36:2, 1997, pp. 207-38, especially 221-24; see the discussion, focused in part on the experience of Birmingham, in Solomos \& Back, Race, Politics and Social Change, pp. 43-50.

${ }^{7}$ N.Deakin, The Politics of the Commonwealth Immigrants Bill', in Political Quarterly, 39:1, 1968, pp. 25-53;

${ }^{8}$ Winder, Bloody Foreigners, p. 362-75.

${ }^{9}$ D. Goodhart, The British Dream: The Successes and Failures of Post-War Immigration (London: Atlantic Books, 2013), p.144.

${ }^{10}$ Saggar, Race and Politics in Britain, pp 121-22.

${ }^{11}$ See the discussion in S. Spencer, 'The impact of immigration policy on race relations', in T.Blackstone, B. Parekh \& P. Sanders, eds., Race Relations in Britain: A Developing Agenda (London: Routledge, 1998), pp. $74-$ 95.

${ }^{12}$ Waters, “"Dark strangers” in our midst', pp. 217-21.

${ }^{13}$ C. Brown, The Death of Christian Britain: Understanding Secularisation 1800-2000 ( $2^{\text {nd }}$ edition, London: Routledge, 2009), pp. 170-75; Grace Davie, Religion in Britain since 1945 (Oxford: Blackwell, 1994), pp. 3033 .

${ }^{14}$ Brown, The Death of Christian Britain, pp. 175-80; J. Anderson, 'The Tory party at prayer?

The Church of England and British politics in the 1950s', in Journal of Church and State, 58:3, 2016, pp. 41739.

${ }^{15}$ Davie, Religion in Britain since 1945, pp. 31, 33-35.

${ }^{16}$ For a broad analysis of church establishment in the UK see M.Morris, ed. Church and State in 21st Century Britain: The Future of Church Establishment (London: Palgrave Macmillan, 2009).

${ }^{17}$ Davie, Religion in Britain since 1945, pp. 25-26.

${ }^{18}$ For a biography of Huddleston see P.McGradle, Trevor Huddleston: Turbulent Priest (London: Continuum, 2004), though most of the focus is on his work in Africa.

${ }^{19}$ See https://www.telegraph.co.uk/news/obituaries/1420227/The-Right-Reverend-Paul-Burrough.html (accessed 18 November 2018). This obituary of Burroughs, who died in 2003, gives some idea of his work in Birmingham before he went to Zimbabwe as a bishop, though there is more scattered about in the archives and the pages of the Church Times during the early 1960s.

${ }^{20}$ A brief discussion can be found in B. Kaye, An Introduction to World Anglicanism(Cambridge: Cambrudge University Press, 2008), pp. 41-63, and scattered throughout K.Ward, A History of Global Anglicanism (Cambridge: Cambridge University Press, 2006).

${ }^{21}$ On some of the early church debates on South Africa see M.Worsnip, Between the Two Fires: The Anglican Church and Apartheid 1948-1957 (Scottsville: University Kwazulu Natal Press, 1996).

${ }^{22}$ Church Times, 18 March 1955.

${ }^{23}$ T.Cantle, Community Cohesion: A New Framework for Race and Diversity (Basingstoke: Palgrave Macmillan, 2005), p. 6.

${ }^{24}$ Church Times, 6 December 1957. 
${ }^{25}$ Church Times, 19 September 1958.

${ }^{26}$ J.Wilkinson, R. Wilkinson \& J.Evans, Inheritors Together (London: Race, Pluralism and Community Group of the Board of Social Responsibility of the Church of England, 1985), p. 13; M.Barton, Rejection, Resistance and Resurrection: Speaking Out on Racism (London: Darton, Longman and Todd, 2005).

${ }^{27}$ O. Chadwick, Michael Ramsey: A Life (Oxford: Oxford University Press, 1991), pp. 165-76.

${ }^{28}$ The Church of England Newspaper, 7 July 1961.

${ }^{29}$ The Church of England Newspaper, 18 August 1961.

${ }^{30}$ The Church of England Newspaper, 28 July 1961.

${ }^{31}$ Church Times, 11 August 1961; The Church of England Newspaper, 10 November 1961.

${ }^{32}$ On the politics of the 1962 act see N.Deakin, 'The politics of the Commonwealth Immigrants Bill', in

Political Quarterly, 39:1, 1968, pp. 25-45; D.Dean, 'The Conservative government and the 961 Commonwealth Immigration Act: the inside story', in Race and Class, 35:2, 1993, pp. 57-74.

${ }^{33}$ Ramsey Papers 6, 1961, f.240, 14 November 1961.

${ }^{34}$ Ramsey Papers 6, 1961, ff. 289-82 \& 287-88.

${ }^{35}$ Hansard, House of Lords Debates, 12 March 1962, Vol. 238, cc. 24-26.

${ }^{36}$ Chadwick, Ramsey, pp. 165-66.

${ }^{37}$ Ramsey Papers 18, 1962, ff. 282-83.

${ }^{38}$ K.Leech, 'Glory in trouble: the social theology of Michael Ramsey', in R.Gill \& L.Kendall, eds., Michael

Ramsey as Theologian (London: Darton, Longman and Todd, 1995), p. 116.

${ }^{39}$ House of Lords Debates, 14 May 1962, vol. 240, cc. 451-55.

${ }^{40}$ On race relations acts see S.Saggar, Race and Politics in Britain (London: Harvester Wheatsheaf, 1992), pp. 79-87.

${ }^{41}$ See Ramsey's speech in 1968. House of Lords Debates, 15 July 1968, vol. 295, cc. 56-60.

${ }^{42}$ Ramsey Papers 75 (1965), ff. 1-3.

${ }^{43}$ Chadwick, Michael Ramsey, p. 166.

${ }^{44}$ Ramsey Papers 75 (1965), ff.54, 79-80.

${ }^{45}$ Ramsey Papers 75 (1965), ff. 177-78, \& 180.

${ }^{46}$ Ramsey Papers 95 (1966), ff. 54-5, 132-33, 213-15.

${ }^{47}$ Ramsey Papers 95 (1966), f.198.

${ }^{48}$ Cf. R,Hansen, 'The Kenyan Asians, British politics and the Commonwealth Immigrants Act, 1968', in the Historical Journal, 42:3, 1999, pp. 809-34; K.Morgan, Callaghan: A Life (Oxford: Oxford University Press, 1997), pp. 306-13.

${ }^{49}$ House of Lords Debates, 29 February 1968, vol 289, cc. 950-54.

${ }^{50}$ Ramsey Papers 129 (1968), ff. 12 \& 35-36.

${ }^{51}$ Ramsey Papers 129 (1968), ff. 58-137 has detailed correspondence and internal memos discussing strategy and how to handle the threatened resignation issues, as well as press cuttings related to this.

${ }^{52}$ Ramsey papers 204 (1971), ff. 27-29.

${ }^{53}$ House of Lords Debates, 24 June 1971, vol. 320, cc 1028-1031.

${ }^{54}$ Church of England Record Office (CERC), CERC, BSR/T/IMM/1, papers relating to the 1971 Immigration Act.

55 Ramsey Papers 243 (1972), ff. 116-7 includes a background paper on Ugandan Asians produced by Douglas Tilbey of the CRRU, noting that in addition to around 50,000 Asians eligible for British passports in Uganda, there were an additional 55,000 in Kenya and 22,000 in Tanzania.

56 Sunday Times, 10 November 1972.

${ }^{57}$ D. Goodhart, The British Dream: The Successes and Failures of Post-War Immigration (London: Atlantic Books, 2013), p.144.

${ }^{58}$ Daily Express, 10 December 1968.

${ }^{59}$ Chadwick, Michael Ramsey: A Life, p.174.

${ }^{60}$ Church Times, 22 November 1968; Ramsey papers 141 (1968), f. 237.

${ }^{61}$ Ramsey Papers 75 (1965), ff. 57-58, 92-93, \& 110-13.

${ }^{62}$ Church Times, 27 August 1965; 3, 10 \& 17 September 1965; 1, 8 \& 15 October 1965.

${ }^{63}$ Ramsey Papers 130 (1968), ff. 2-3.

${ }^{64}$ Ibid., f. 15.

${ }^{65}$ Ibid.,ff. 289-95.

${ }^{66}$ E.J.B.Rose, et.al., Colour and Citizenship: A Report on British Race Relations (London: Oxford University Press and Institute of Race Relations, 1969), pp. 370-80.

${ }^{67}$ House of Lords Debates, 16 December 1969, vol 306, cc. 992-6.

${ }^{68}$ K.Leech, 'The Church and immigration and race relations policy', p. 211.

${ }^{69}$ Cf. Church Times, 16 \& 23 July 1976; Coggan Papers 40 (1976), ff. 203-4.

${ }^{70}$ Coggan Papers 40 (1976), ff. 206, 192, \& 200-1. 
${ }^{71}$ British Council of Churches, The New Black Presence in Britain: A Christian Scrutiny (A statement by the BCC Working Group on Britain as a Multi-Racial Society, London, British Council of Churches, Community and Race Relations Unit, 1976).

${ }^{72}$ For a brief profile of Gus John see https://www.georgepadmoreinstitute.org/prof-gus-john (accessed 21 January 2019).

${ }^{73}$ The New Black Presence, pp. 3-6.

${ }^{74}$ Ibid., pp. 7-17.

${ }^{75}$ Ibid., pp. 32-34

${ }^{76}$ CERC, BSR/T/RACE/2, 7 September 1976.

${ }^{77}$ Ibid., 18 August 1976.

${ }^{78}$ Ibid., 9 March 1977.

79 The full debate in Report of Proceedings General Synod, 1977, Vol. 8 (2), pp. 513-64.

${ }^{80}$ Church Times, 9 September 1977.

${ }^{81}$ Church Times, 12 August 1977 \& 2 September 1977.

${ }^{82}$ Coggan Papers 70 (1978), f.161, 165-66; for more discussion of church responses to racism see K.Leech, Struggle in Babylon: Racism in the Cities and Churches of Britain (London: Sheldon Press, 1988), pp. 61-97.

${ }^{83}$ Saggar, Race and Politics in Britain, pp. 121-22.

${ }^{84}$ Coggan Papers 71 (1978), ff. 104-6.

${ }^{85}$ Church Times, 3 March 1978; Coggan Papers 71 (1978), ff. 97-98; CERC, BSR/T/IMM/2.

${ }^{86}$ E.Burton, From Assimilation to Anti-Racism: The Church of England's Response to Afro-Caribbean

Migration, 1948-81 (PhD Dissertation, UWE, 2004), pp. 382-92. 